\title{
Tipologi Petani dalam Keberagaman Usahatani Sayur di Desa Erelembang Kecamatan Tombolopao Kabupaten Gowa
}

\author{
Ardi Rumallang*, dan Akbar \\ Universitas Muhammadiyah Makassar \\ Jl. Sultan Alauddin No. 259 Makassar \\ *Alamat korespondensi: ardi.rumallang@unismuh.ac.id
}

\begin{tabular}{|c|c|}
\hline INFO ARTIKEL & ABSTRACT/ABSTRAK \\
\hline Diterima: $14-12-2021$ & \\
\hline Direvisi: $\quad$ 17-01-2022 & The Typology of Farmers in the Diversity of Vegetable Farming in \\
\hline Dipublikasi:23-01-2022 & Erelembang Village Tombolopao District Gowa Regency \\
\hline
\end{tabular}

Keywords:

Farming, Typology of farmer, Vegetable diversity
Kata Kunci:

Keberagaman sayur, Tipologi petani, Usahatani
Typology of farmers in the diversity of vegetable farming is the character of vegetable farmers in undertaking farming. This study aimed to examine the typology of farmers and analyze the relationship between the typology of farmers in the diversity of vegetable farming in Erelembang Village, Kunciopao District, Gowa Regency. The study was conducted from May August 2021 using a survey method with the determination of the sample using simple random sampling. The data analysis technique used was descriptive qualitative and Pearson correlation. The results showed that the typology of farmers in the diversity of vegetable farming in Erelembang Village, Tombolopao District, Gowa Regency were based on land area, orientation or farming purposes, technology and characteristics of farmers. The typology of farmers based on land area on the diversity of farming had a sufficient relationship (correlation value 0.48 ) and included in the category of sufficient correlation which meant that farmers who had sufficient land area allowed the diversity of vegetable farming to be carried out. The typology of farmers based on the orientation or purpose of farming on the diversity of farming had a correlation value of 0.81 indicated a very strong relationship or correlation, which considered that the number of vegetable commodities cultivated by farmers was largely determined by this variable with the commodity being cultivated were potatoes, tomatoes, cabbage, spring onion and green bean. Similarly, the relationship of farmer typology based on characteristics of farmers to the diversity of vegetable farming cultivated by farmers included in a very strong correlation (correlation value 0.84 ) and had a very strong relationship, implied that farmer typology based on characteristics of farmers greatly determined the diversity of vegetable farming that will be cultivated by farmers at the research site.

Tipologi petani dalam keberagaman usahatani sayur merupakan karakter petani sayur dalam melakukan usahatani. Penelitian ini bertujuan untuk mengakaji tipologi petani dan menganalisis hubungan tipologi petani dalam keberagaman usahatani sayur di Desa Erelembang, Kecamatan Tombolopao, Kabupaten Gowa. Penelitian dilakukan dari bulan Mei - Agustus 2021 menggunakan metode survei dengan penentuan sampel menggunakan simple random sampling. Teknik analisis data yang digunakan deskrptif kualitatif dan korelasi pearson. Hasil penelitian menunjukkan bahwa tipologi petani dalam keberagaman usahatani sayur di Desa Erelembang, Kecamatan Tombolopao, Kabupaten Gowa yaitu tipologi berdasarkan luas lahan, tipologi 
berdasarkan orientasi atau tujuan bertani, tipologi berdasarkan teknologi, serta tipologi berdasarkan sifat yang dimiliki petani. Tipologi petani berdasarkan luas lahan terhadap keberagaman usahatani memiliki hubungan yang cukup (nilai korelasi 0,48 ) dan termasuk kategori korelasi cukup yang berarti petani yang memiliki luas lahan yang cukup maka memungkinkan adanya keberagamaan usahatani sayur yang dilakukan. Tipologi petani berdasarkan orientasi atau tujuan berusahatani terhadap keberagaman usahatani memiliki nilai korelasi 0,81 menunjukkan adanya hubungan atau korelasi yang sangat kuat yang artinya bahwa banyaknya komoditi sayur yang diusahakan oleh petani sangat ditentukan oleh tipologi petani berdasarkan tujuan dalam melakukan usahatani dengan komoditi yang diusahakan adalah kentang, tomat, kubis, daun bawang dan buncis. Demikian juga dengan hubungan tipologi petani berdasarkan sifat terhadap keberagaman usahatani sayur yang diusahakan oleh petani termasuk korelasi sangat kuat (nilai korelasi 0,84) dan memiliki hubungan yang sangat kuat, artinya bahwa tipologi petani berdasarkan sifat sangat menentukan keberagaman usahatani sayur yang akan diusahakan oleh petani di lokasi penelitian.

\section{PENDAHULUAN}

Tanaman sayuran merupakan jenis komoditi yang memiliki nilai ekonomi tinggi dan berperan penting dalam pemenuhan berbagai kebutuhan gizi masyarakat (Ningsih dkk., 2016). Ketersediaan komoditi sayuran di masyarakat melibatkan petani sebagai produsen, stakeholder yang menyiapkan dan memasarkan serta pengguna hasil produksi sayuran dalam perannya masing-masing. Petani melaksanakan peran dalam memproduksi, pedagang berperan dalam mendistribusikan produksi sampai kepada konsumen dan konsumen berperan dalam memakai hasil produksi untuk memenuhi kebutuhannya.

Namun demikian, kebutuhan sayuran yang semakin meningkat tidak diikuti dengan produksi sayuran yang cenderung stagnan bahkan menurun (Rumallang, 2019). Kondisi lebih buruk pada masa sekarang ini dimana Ashari dkk. (2020) melaporkan petani sayuran di sejumlah daerah di Indonesia mengalami dampak negatif pandemi Covid-19 sehingga pendapatan mereka menurun drastis dengan contoh kasus di satu daerah pemasukan ke pasar tradisional dan pasar induk hanya $10 \%$ dari saat normal.

Secara umum, produksi pertanian dipengaruhi oleh faktor produksi diantaranya lahan, tenaga kerja, modal dan kemampuan manajemen (Mandang dkk., 2020). Demikian juga dengan petani sayuran, produksi sayuran sangat ditentukan oleh faktorfaktor produksi seperti luas lahan, bibit, pupuk dan tenaga kerja (Lamusa, 2005). Produksi sayuran ini merupakan salah satu jenis usahatani yang dilakukan untuk mendatangkan kesempatan kerja dan perolehan pendapatan (Ningsih dkk., 2016). Melalui usahatani ini, petani dapat memenuhi kebutuhan serta meningkatkan kesejahteraan hidup keluarganya (Rumallang, 2019). Desa Erelembang, Kecamatan Tombolopao, Kabupaten Gowa merupakan salah satu sentra penanaman sayur, dimana sepanjang tahun petani melakukan usahtani sayuran berupa usahatani kentang, kol, tomat, sawi, daun bawang dan buncis.

Keberagaman usahatani sayuran di daerah tersebut merupakan bagian dari tipologi petani yang dimiliki oleh daerah setempat. Jenis tanaman yang dibudidayakan dalam suatu usahatani terbentuk melalui proses pengalaman dengan mempertimbangkan hemat tenaga, waktu, dan biaya perawatan (Mandang dkk., 2020). Semakin banyak atau beragam usahatani yang dilakukan oleh petani maka semakin membuka peluang penambahan pendapatan petani semakin meningkat. Demikian juga sebaliknya semakin sedikit usahatani yang dilakukan oleh petani sayur maka semakin sedikit pula peluang penambahan pendapatan yang dimiliki oleh petani.

Tipologi petani sangat berpengaruh terhadap penelolaan usahatani yang mereka lakukan. Petani yang melakukan usahatani sayur yang sejenis atau beragam jenis dalam satu musim tanam itu bagian dari pengambaran tipologi petani. Petani yang hanya menanam satu jenis komoditi dalam satu musim tanam maka sumber pendapatan usahataninya hanya satu.

Hal ini berbeda dengan petani yang melakukan usahatani bermacam-macam komoditi 
dalam satu kali musim tanam, sumber pendapatan usahatani mereka sesuai dengan jumlah komoditi yang mereka usahakan. Tujuan penelitian ini adalah untuk mengetahui dan menganalisis tipologi petani dalam keberagaman usahatani sayur dan menganalisis hubungan tipologi petani dalam keberagaman usahatani sayur di Desa Erelembang, Kecamatan Tombolopao Kabupaten Gowa.

\section{BAHAN DAN METODE}

\section{Lokasi Penelitian}

Penelitian dilaksanakan di Desa Erelembang, Kecamatan Tombolopao, Kabupaten Gowa. Pemilihan lokasi penelitian berdasarkan pertimbangan bahwa lokasi tersebut merupakan sentra pengembangan dan penanaman sayuran. Penelitian berlangsung dari bulan Mei sampai dengan bulan Agustus 2021.

\section{Populasi dan Sampel}

Populasi dan sampel dalam penelitian ini adalah petani sayur yang tiap musim melakukan usahatani sayur. Jumlah petani sayur di Desa Erelembang sebanyak 435 orang. Sampel dalam penelitian ini sebanyak 44 orang dengan mengambil $10 \%$ dari jumlah populasi dengan menggunakan teknik random sampling.

\section{Sumber dan Teknik Pengumpulan Data}

Data yang digunakan dalam penelitian ini adalah data sekunder yang dipublikasikan oleh Badan Pusat Statistik (BPS) dan Instansi Pemerintah terkait lainnya serta dan data primer yang diperoleh langsung dari responden. Pengumpulan data dilakukan melalui wawancara menggunakan kuisioner, dokumentasi dan foto-foto di lokasi penelitian. Secara operasional kerangka penelitian yang digunakan untuk memudahkan pelaksanaan penelitian disajikan pada Gambar 1 .

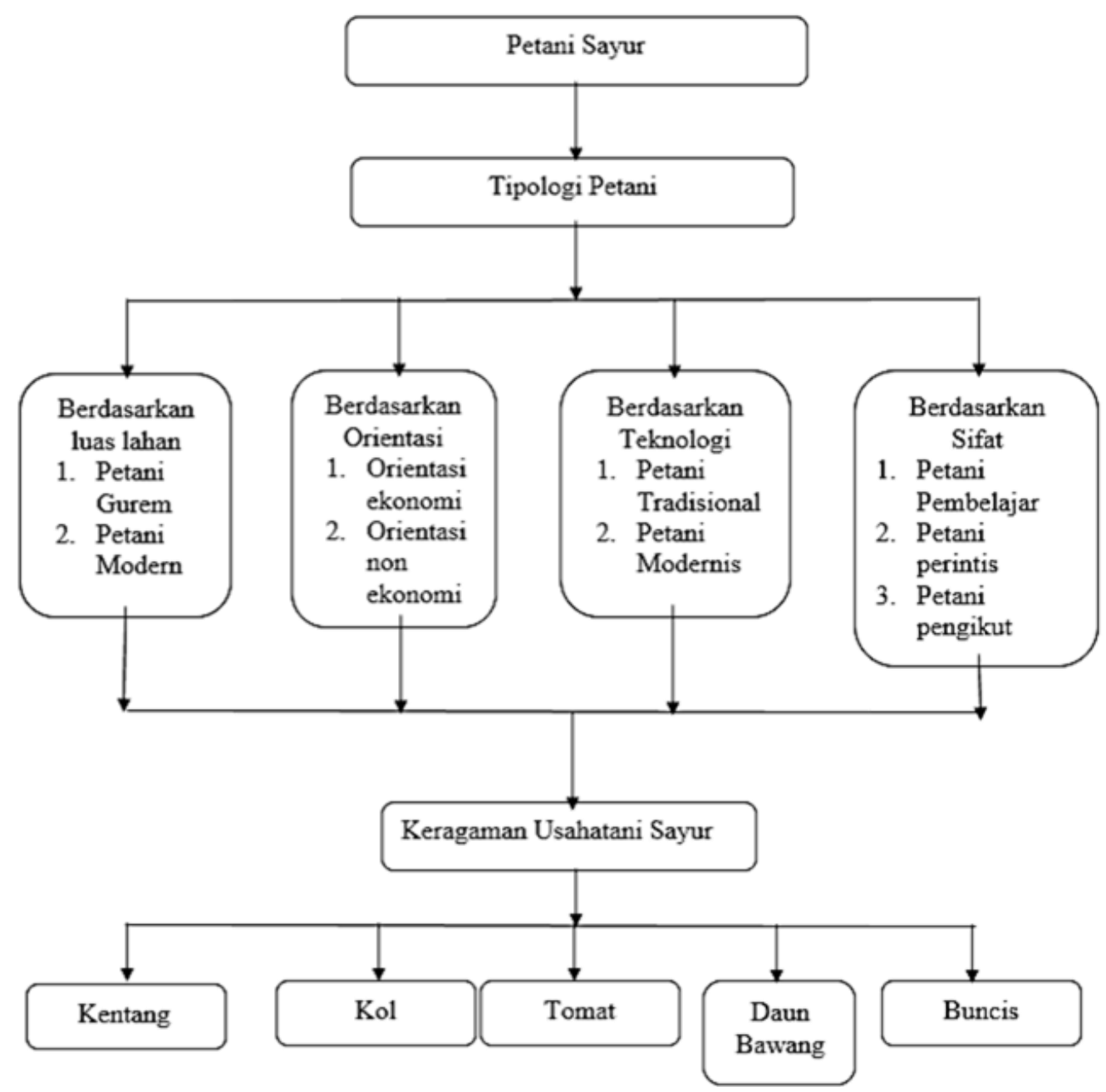

Gambar 1. Kerangka pemikiran operasional penelitian 


\section{Analisis Data}

Analisis tipologi petani dalam keberagaman usahatani sayur dilakukan menggunakan analisis deskriptif kaulitatif yaitu menjelaskan secara mendalam dan terperinci tentang tipologi petani dalam keberagaman usahatani sayur. lebih lanjut menggunakan analisis korelasi person dengan rumus:

$$
r=\frac{\sum x y-\frac{\left(\sum x\right)\left(\sum y\right)}{n}}{\sqrt{\left(\sum x^{2}-\frac{\left(\sum x\right)^{2}}{n}\right)\left(\sum y^{2}-\frac{\left(\sum y\right)^{2}}{n}\right)}}
$$

Keterangan:

$\mathrm{r}=$ nilai korelasi

$\mathrm{x}=$ variabel $\mathrm{x}$ (tipologi petani)

$\mathrm{y}=$ variabel y (keberagaman usahatani sayur)

Kekuatan hubungan korelasi menurut Sarwono (2006) adalah sebagai berikut:

$0 \quad$ : Tidak ada korelasi

$0.00-0.25$ : korelasi sangat lemah

$0.25-0.50$ : korelasi cukup

$0.50-0.75$ : korleasi kuat

$0.75-0.99$ : korelasi sangat kuat

1 : korelasi sempurna

\section{HASIL DAN PEMBAHASAN}

\section{Tipologi Petani Berdasarkan Luas Lahan}

Berdasarkan penelitian yang telah dilakukan maka dapat dijelaskan bahwa tipologi petani dalam keberagaman usahatani sayur terbagi menjadi dua yaitu petani gurem dan petani modern. Hal ini sejalan dengan pendapat Mosher (1997) bahwa tipologi petani berdasarkan luas lahan yang dimiliki terbagi menjadi tiga yaitu: 1) petani gurem yaitu petani yang memiliki luas lahan di bawah dari 0,25 ha, 2) petani modern yaitu petani yang memiliki atau menguasai lahan lebih dari 0,25 ha dan dalam pengelolaan usahataninya menggunakan teknologi, dan 3) petani primitif yaitu petani yang dalam berusahatani dengan cara berpindah-pindah. Tipologi petani berdasarkan luas lahan yang dimiliki di lokasi penelitian disajikan pada Tabel 1 .
Tabel 1. Tipologi petani berdasarkan luas lahan yang dimiliki di lokasi penelitian

\begin{tabular}{lcc}
\hline Tipologi Petani & Jumlah & Persentase (\%) \\
\hline Petani gurem & 3 & 6,80 \\
Petani modern & 41 & 93,20 \\
\hline Jumlah & 44 & 100,00 \\
\hline
\end{tabular}

Beradsarkan Tabel 1 di atas menunjukkan bahwa di lokasi penelitian petani gurem terdapat 3 orang dengan persentase $6,8 \%$ sedangkan petani modern sebanyak 37 orang dengan persentase 93,20\%. Petani gurem yang ada di lokasi penelitian adalah petani baru. Dengan demikian, dari hasil ini dapat disimpulkan bahwa secara umum petani di lokasi penelitian berdasarkan luas lahan termasuk petani modern.

\section{Tipologi Petani Berdasarkan Tujuan Bertani}

Tipologi petani berdasarkan tujuan bertani di lokasi penelitian yaitu petani yang berorientasi ekonomi dan petani yang berorientasi non ekonomi (Tabel 2). Tipologi petani berorientasi ekonomi adalah petani yang melakukan usahatani sayur dengan tujuan untuk meningkatkan ekonomi yang berorientasi keuntungan. Biaya yang dikeluarkan dicatat dalam pembukuan usaha dengan konsep biaya yang dikeluarkan seefisien mungkin untuk kepentingan keuntungan semaksimal mungkin dan semua produksi yang dihasilkan dinilai dengan rupiah.

Nilai rupiah yang akan diterima oleh petani tentunya petani menjual hasil produksinya kepada pedagang yang ada di wilayah tersebut. Terdapat beberapa pedagang pengumpul dan padagang besar dalam membantu memasarkan produksi para petani di lokasi penelitian (Rumallang dkk., 2019). Petani yang berorientasi non ekonomi adalah petani yang melakukan usahatani untuk keperluan dan kebutuhan keluarga dan produksi yang dihasilkan ditujukan kepada konsumsi keluarga (Tarigan \& Suhaeti, 2018).

Tabel 2. Tipologi petani berdasarkan orientasi atau tujuan bertani di lokasi penelitian

\begin{tabular}{lcc}
\hline \multicolumn{1}{c}{ Tipologi petani } & Jumlah (orang) & Persentase (\%) \\
\hline Berorientasi ekonomi & 2 & 4,55 \\
Berorientasi non ekonomi & 4 & 9,09 \\
Komparasi petani berorientasi pada ekonomi dan & 38 & 86,36 \\
berorientasi non ekonomi & & \\
\hline Jumlah & 44 & 100,00 \\
\hline
\end{tabular}


Data pada Tabel 2 menunjukkan bahwa terdapat dua orang atau $4,55 \%$ petani yang berorientasi ekonomi. Petani yang berorientasi ekonomi ditandai dengan semua biaya yang dikeluarkan dihitung dengan baik dalam buku catatan serta produksi yang dihasilkan dijual untuk tujuan mendapatkan keuntungan maksimal. Terdapat empat orang atau sekitar $9,09 \%$ petani yang berorientasi non ekonomi. Menurut (Rumallang, 2019), tinggi rendahnya pendapatan petani yang berorientasi ekonomi sangat ditentukan dengan sistem bagi hasil para petani dalam melakukan usahatani sayur. Di lokasi penelitian terdapat beberapa sistem bagi hasil yaitu untuk tanaman kentang dan tomat dengan sistem 3:1 (dua bagian untuk pemilik modal dan satu bagian untuk petani penggarap), untuk tanaman kubis, wortel dan buncis dengan sistem 2:1 (satu bagian untuk petani pemilik modal dan satu bagian untuk petani penggarap). Petani yang berorientasi non ekonomi melakukan usaha tani hanya untuk dimakan keluarga dan diberikan secara gratis kepada tetangga atau kepada orang-orang yang membutuhkan. Petani jenis ini rasa sosialnya lebih tinggi daripada petani yang berorientasi ekonomi yang cenderung memiliki rasa sosial yang rendah. Petani yang berorientasi non ekonomi adalah petani yang memiliki pekerjaan lain selain pekerjaan sebagai petani, seperti guru, tukang batu dan bengkel. Terdapat tipologi petani yang baru di lokasi penelitian yaitu komparasi petani berorientasi ekonomi dan non ekonomi (Tabel 2).

Tipologi petani jenis ini adalah petani yang memadukan antara kepentingan ekonomi dan kepentinga kebutuhan keluarga serta memberikan kepada tetangga dan orang yang membutuhkan. Petani dengan tipologi ini yang paling banyak di lokasi penelitian. Terdapat 38 petani atau sekitar $86,36 \%$ petani yang mengkomparasikan dalam berusahatani orientasi ekonomi dan non ekonomi. Tipologi petani jenis ini memiliki rasa tanggungjawab yang tinggi kepada kebutuhan ekonomi keluarga, kebutuhan yang akan dimakan keluarga dan nilai sosial yang tinggi kepada sesama masyarakat. Tipologi seperti ini merupakan tipologi yang harus dijaga dan dikembangkan oleh petani di lokasi penelitian.

\section{Tipologi Petani Berdasarkan Teknologi}

Tipologi petani berdasarkan teknologi yaitu petani tradisional dan petani modern. Petani tradisional adalah petani yang melakukan usahatani menggunakan alat-alat pertanian tradisional seperti menggunakan cangkul dalam mengolah atau membajak lahan yang dimilikinya, sedangkan petani modern adalah petani yang menggunakan alat-alat pertanian yang modern (Mosher, 1997). Petani di lokasi penelitian sudah termasuk petani modern karena semua petani sudah menggunakan alat pertanian yang modern dalam melakukan usahataninya. Teknologi yang digunakan petani di lokasi penelitian seperti dalam pengolahan atau pembajakan lahan memakai hand tractor, dalam penyemprotan memakai mesin semprot dari berbagi jenis mesin semprot, dalam penyiraman memakai kincir air (sprinkler) serta dalam penyediaan air menggunakan mesin air. Dalam hal informasi petani lebih banyak menggunakan internet dalam mencari informasi dan solusi dari masalah yang mereka hadapi dalam melakukan usahatani. Petani di lokasi penelitian menggunakan teknologi secara maksimal dalam melakukan usaha yang mereka jalankan.

\section{Tipologi Petani Berdasarkan Sifat}

Tipologi petani berdasarkan sifat di lokasi penelitian terdapat tiga tipe petani yaitu petani pembelajar, petani perintis dan petani pengikut (Tabel 3). Tipologi petani berdasarkan sifat yang terbagi menjadi tiga tipe petani pembelajar, petani perintis dan petani pengikut diterangkan oleh Mosher (1997). Petani pembelajar adalah petani yang selalu belajar dan mencari informasi secara mandiri, suka memulai hal-hal yang baru dan suka dengan tantangan. Petani perintis adalah petani yang selalu memulai hal-hal yang baru yang belum dilakukan oleh orang lain, dialah orang yang paling pertama mangadopsi informasi yang didapatkan melalui internet atau informasi dari buku, media cetak dan informasi dari petani di luar daearahnya. Petani seperti ini selalu mencari informasi yang belum dilakukan oleh orang lain sehingga cenderung lebih maju daripada petani yang lain. Petani pengikut adalah petani yang melakukan sesuatu karena sudah melihat petani di sekitarnya sudah melakukannya. Petani seperti ini tidak membutuhkan informasi dari media seperti internet, buku/majalah, dan media elektronik lainnya.

Tabel 3. Tipologi petani berdasarkan sifat yang dimiliki di lokasi penelitian

\begin{tabular}{lcc}
\hline \multicolumn{1}{c}{ Tipologi petani } & Jumlah (org) & Persentase (\%) \\
\hline Petani Pembelajar & 10 & 22,72 \\
Petani Perintis & 5 & 11,36 \\
Petani Pengikut & 39 & 88,63 \\
\hline Jumlah & 44 & 100,00 \\
\hline
\end{tabular}


Data pada Tabel 3 menunjukkan bahwa tipologi petani pembelajar terdapat 10 orang atau sekitar 22,72\%. Petani pembelajar ini selalu yang terdepan dalam adopsi inovasi, selalu melakukan sesuatu yang baru dan sangat suka dengan tantangan. Mereka berani mengambil resiko dari usahatani yang dilakoninya. Tipologi petani perintis sebanyak 5 orang atau sekitar 11,36\%. Petani perintis selalu mencari informasi yang belum didapatkan oleh orang lain, selalu menjadi orang yang pertama melakukan sesuatu yang dianggap memberikan sumbangsi dalam usahataninya, bersifat kreatif dan aktif dalam mencari informasi dan ide baru yang akan diterapkan dalam usahataninya. Petani jenis ini merupakan petani yang memiliki pendidikan yang lebih tinggi dibandingkan dengan petani yang lain. Sementara itu, terdapat 39 orang atau sekitar $88,63 \%$ petani pengikut. Petani pengikut adalah petani yang melakukan sesuatu ketika orang lain sudah melakukannya, petani seperti ini mengikuti apa yang telah dilakukan oleh petani pembelajar dan petani perintis, sehingga petani serperti ini cenderung pasif dalam teknologi baru yang ada. Petani seperti ini adalah petani yang memiliki pendidikan sekolah dasar dan bahkan tidak tamat dalam bangku sekolah.

\section{Tipologi Petani dalam Keberagaman Usahatani Sayur} Tipologi petani dalam keberagaman usahatani sayur di lokasi penelitian bervariasi (Tabel 4). Beberapa tipologi petani melakukan usahatani sayur sebanyak dua komoditi yaitu komoditi kentang dan buncis atau kentang dan tomat. Tipologi petani yang lain sebanyak enam komoditi yaitu kentang, tomat, wortel, kubis, daun bawang, dan buncis. Keberagaman usahatani sayur yang diusahakan oleh petani maka menjadikan konsumsi rumah tangga bervariasi, begitupun dengan kebutuhan gizi berupa serat yang menjadi kebutuhan manusia akan lebih terjamin (Astawan, 2007 dalam Lingga 2018).

Tabel 4. Tipologi petani dalam keberagaman usahatani sayur di lokasi penelitian

\begin{tabular}{lcc}
\hline \multicolumn{1}{c}{ Tipologi petani } & $\begin{array}{c}\text { Jumlah komoditi } \\
\text { yang diusahakan }\end{array}$ & $\begin{array}{c}\text { Komoditi sayur } \\
\text { yang diusahakan }\end{array}$ \\
\hline Petani Gurem & \multicolumn{2}{c}{ Berdasarkan luas lahan } \\
Petani Modern & 2 & Kentang, buncis \\
& 6 & Kentang, tomat, wortel, kubis, daun bawang, buncis \\
\hline Ekonomi & 2 & Berdasarkan orientasi \\
Non Ekonomi & 6 & Kentang, dan tomat \\
Komparasi Ekonomi & 6 & Kentang, tomat, wortel, kubis, daun bawang, buncis \\
dan non ekonomi & & Kentang, tomat, wortel, kubis, daun bawang, buncis \\
\hline & 0 & Berdasarkan penggunaan teknologi \\
\hline Tradisional & 6 & Kentang, tomat, wortel, kubis, daun bawang, buncis \\
Modern & & Berdasarkan sifat \\
\hline & 6 & Kentang, tomat, wortel, kubis, daun bawang, buncis \\
Pembelajar & 6 & Kentang, tomat, wortel, kubis, daun bawang, buncis \\
Perintis & 6 & Kentang, tomat, wortel, kubis, daun bawang, buncis \\
\hline
\end{tabular}

Data pada Tabel 4 menunjukkan bahwa keberagaman usahatani sayur tipologi petani gurem sebanyak dua komoditi yaitu komoditi kentang dan buncis. Petani dengan tipologi ini tidak bisa menambah komoditi yang diusahakan karena petani hanya memiliki luas lahan tidak lebih dari 0,25 ha, tergolong petani skala kecil menurut Susilowati dan Maulana (2012), sehingga hanya memaksimalkan usahataninya di lahan yang sempit tersebut. Demikian juga dengan tipologi petani ekonomi melakukan usahatani sebanyak 2 komoditi yaitu kentang dan tomat. Tipologi Petani ini bukan karena lahan yang dimilikinya sempit tetapi petani berpikir bahwa komoditi yang mereka usahakan adalah komoditi memiliki nilai ekonomi yang tinggi dan menjanjikan.

Tipologi petani seperti ini cenderung memiliki nilai sosial dan kepedulian yang rendah dibandingkan dengan petani yang lain. Tipologi petani yang melakukan lebih beragam usahatani sayur yaitu 
tipologi petani modern, non ekonomi, komparasi ekonomi dan non ekonomi, pembelajar, perintis dan pengikut. Tipologi petani ini melakukan usahatani sangat beragam yaitu komoditi, kentang, tomat, kubis, wortel, daun bawang dan buncis, sehingga petani tipologi ini mempunyai kebebasan dalam memilih komoditi yang akan diusahakan karena didukung oleh lahan yang dimiliki, karakter dan pola manajerial yang dimiliki.

Kebanyakan petani tipologi semacam ini melakukan usahatani dengan sistem tumpang sari, sistem polikultur dan sistem tanam bergilir. Di sisi lain tipologi petani jenis ini memiliki rasa sosial yang tinggi dan kepedulian terhadap orang lain. Pada komunitas mereka mengedepankan sifat kerjasama atau gotong royong dalam segala hal yang akan mereka lakukan, sehingga hidup bersama merupakan sesuatu yang harus dijaga dan terus dikembangkan dalam usahatani sayur yang mereka lakukan.

\section{Hubungan Tipologi Petani terhadap Keberagaman Usaha Tani Sayur}

Hubungan tipilogi petani dengan keberagaman usahatani sayur yang diusahakan oleh petani sayur dapat dilihat dari nilai korelasi. Hasil analisis menunjukkan bahwa ada hubungan antara tipologi petani terhadap keberagaman usahatani yang diusahakan dilokasi penelitian. Data pada Tabel 5 menunjukkan bahwa nilai korelasi antara tipologi petani berdasarkan luas lahan terhadap keberagaman usahatani sayur adalah 0,48 yang berarti bahwa variabel tersebut memiliki hubungan dan termasuk kategori korelasi cukup, artinya bahwa petani yang memiliki luas lahan yang cukup maka memungkinkan adanya keberagamaan usahatani sayur yang dilakukan oleh petani di lokasi penelitian.

Tipologi petani berdasarkan orientasi atau tujuan berusahatani terhadap keberagaman usahatani yang diusahakan petani dengan nilai korelasi 0,81 menunjukkan adanya hubungan atau korelasi yang sangat kuat, artinya bahwa banyaknya komoditi sayur yang diusahakan oleh petani sangat ditentukan oleh tipologi petani berdasarkan tujuan dalam melakukan usahatani. Komoditi yang diusahakan oleh petani yaitu komoditi kentang, tomat, kubis, daun bawang dan buncis.

Hubungan tipologi petani berdasarkan sifat terhadap keberagaman usahatani sayur yang diusahakan oleh petani ditunjukkan dengan nilai korelasi. Nilai korelasi sebesar 0,84 yang berarti termasuk korelasi sangat kuat atau memiliki hubungan yang sangat kuat, artinya bahwa tipologi petani berdasarkan sifat sangat menentukan keberagaman usahatani sayur yang akan diusahakan oleh petani di lokasi penelitian. Dengan demikian, dapat dipahami bahwa banyaknya atau beragamnya usahatani yang dilakukan oleh petani dilokasi penelitian ditentukan dengan tipologi petani yaitu tipologi petani berdasarkan luas lahan, berdasarkan orientasi atau tujuan berusahatani dan berdasarkan sifat yang dimiliki oleh petani (Tabel 5).

Tabel 5. Hubungan tipologi petani terhadap keberagaman usahatani sayur di lokasi penelitian

\begin{tabular}{|c|c|c|c|c|c|}
\hline & & $\begin{array}{l}\text { Tipologi } \\
\text { berdasarkan } \\
\text { luas lahan }\end{array}$ & $\begin{array}{l}\text { Tipologi } \\
\text { berdasarkan } \\
\text { tujuan }\end{array}$ & $\begin{array}{l}\text { Tipologi } \\
\text { berdasarkan } \\
\text { sifat }\end{array}$ & $\begin{array}{c}\text { Keberagaman } \\
\text { usahatani } \\
\text { sayur }\end{array}$ \\
\hline \multirow{3}{*}{$\begin{array}{l}\text { Tipologi } \\
\text { berdasarkan } \\
\text { luas lahan }\end{array}$} & Pearson Correlation & 1 & -0.081 & 0.243 & 0.48 \\
\hline & Sig. (2-tailed) & & 0.601 & 0.112 & 0.059 \\
\hline & $\mathrm{N}$ & 44 & 44 & 44 & 44 \\
\hline \multirow{3}{*}{$\begin{array}{l}\text { Tipologi } \\
\text { berdasarkan } \\
\text { tujuan }\end{array}$} & Pearson Correlation & -0.081 & 1 & 0.025 & 0.81 \\
\hline & Sig. (2-tailed) & 0.601 & & 0.871 & 0.041 \\
\hline & $\mathrm{N}$ & 44 & 44 & 44 & 44 \\
\hline \multirow{3}{*}{$\begin{array}{l}\text { Tipologi } \\
\text { berdasarkan } \\
\text { sifat }\end{array}$} & Pearson Correlation & 0.243 & 0.025 & 1 & 0.84 \\
\hline & Sig. (2-tailed) & 0.112 & 0.871 & & 0.037 \\
\hline & $\mathrm{N}$ & 44 & 44 & 44 & 44 \\
\hline \multirow{3}{*}{$\begin{array}{l}\text { Keberagaman } \\
\text { usahatani } \\
\text { sayur }\end{array}$} & Pearson Correlation & 0.48 & 0.81 & 0.84 & 1 \\
\hline & Sig. (2-tailed) & 0.059 & 0.041 & 0.037 & \\
\hline & $\mathrm{N}$ & 44 & 44 & 44 & 44 \\
\hline
\end{tabular}




\section{SIMPULAN}

Dari hasil penelitian yang telah dilakukan maka dapat disimpulkan:

1. Tipologi petani dalam keberagaman usahatani sayur di Desa Erelembang, Kecamatan Tombolopao, Kabupaten Gowa adalah tipologi berdasarkan luas lahan, tipologi berdasarkan orientasi atau tujuan bertani, tipologi berdasarkan teknologi serta tipologi berdasarkan sifat yang dimiliki petani.

2. Nilai korelasi tipologi petani berdasarkan luas lahan terhadap keberagaman usahatani sayur adalah 0,48 yang berarti bahwa variabel tersebut memiliki hubungan yang cukup dan termasuk kategori korelasi cukup. Tipologi petani berdasarkan orientasi atau tujuan berusahatani terhadap keberagaman usahatani yang diusahakan petani dengan nilai korelasi 0,81 menunjukkan adanya hubungan atau korelasi yang sangat kuat. Demikian juga dengan hubungan tipologi petani berdasarkan sifat terhadap keberagaman usahatani sayur yang diusahakan oleh petani dengan nilai korelasi sebesar 0,84 termasuk korelasi sangat kuat atau memiliki hubungan yang sangat kuat.

\section{DAFTAR PUSTAKA}

Ashari, M Syukur, dan SM Pasaribu. 2020. Pembiayaan usaha pertanian merespons dampak pandemi COVID-19. Dampak Pandemi Covid-19 Perspektif Adaptasi dan Resiliensi Sosial Ekonomi Pertanian (A Suryana, IW Rusastra, T Sudaryanto, SM Pasaribu, Ed.). IAARD Press. Jakarta. Hlm. 235-254.

Lamusa, A. 2005. Faktor-Faktor yang mempengaruhi produksi kangkung air di Desa Tulo Kecamatan Dolo Kabupaten Donggala
Provinsi Sulawesi Tengah. J. Agroland. 12(4): 512-517.

Lingga, RM, A Mukti, dan J Wardie. 2018. Strategi pengembangan usahatani sayuran di Kelurahan Kalampangan Kecamatan Sabangau Kota Palangka Raya. J-SEA (Journal Socio Economics Agricultural). 13(1): 64-78.

Mandang, M, MFL Sondakh, dan OEH Laoh. 2020. Karakteristik petani berlahan sempit Di Desa Tolok Kecamatan Tompaso. AgriSosioEkonomi. 16(1): 105-114.

Mosher, AT. 1997. Menggerakkan dan Membangun Pertanian. Yasa Guna. Jakarta.

Ningsih, S, Yusmini, dan Eliza. 2016. Analisis kontribusi pendapatan usahatani sayuran daun terhadap pendapatan rumah tangga. Indonesian Journal of Agricultural Economics (IJAE). 7(2): 1-12.

Rumallang, A, Jumiati, Akbar, dan Nadir. 2019. Analisis struktur, perilaku dan kinerja pemasaran kentang di Desa Erelembang Kecamatan Tombolopao Kabupaten Gowa. Jurnal Agrikultura. 30(3): 83-90.

Rumallang, A. 2019. Kajian bagi hasil dan pendapatan petani berbasis komoditi di Desa Erelembang Kecamatan Tombolopao Kabupaten Gowa. ZIRAA'AH. 44(3): 326- 336.

Sarwono, J. 2006. Metode Penelitian Kualitatif dan Kuantitatif. Graha Ilmu. Yokyakarta.

Susilowati, SH, dan M Maulana. 2012. Luas lahan usahatani dan kesejahteraan petani: Eksistensi petani gurem dan urgensi kebijakan reforma agraria. Analisis Kebijakan Pertanian. 10(1): 17-30.

Tarigan, H, dan RN Suhaeti. 2018. Karakteristik komersial dan perubahan sosial petani kecil. Forum Penelitian Agro Ekonomi. 36(2): 129144. 